\title{
E-PROCUREMENT ADOPTION IN GOVERNMENT INSTITUTION: PREDICTING SOCIAL VALUES EFFECT ON INTENTION AND USAGE BEHAVIOR OF E-PROCUREMENT
}

\author{
Hery Suliantoro* \\ Diponegoro University \\ Imam Ghozali \\ Diponegoro University \\ Mochamad Agung Wibowo \\ Diponegoro University
}

\begin{abstract}
The main purpose of this paper is to examine empirically the influence of social factors on the adoption of e-Procurement in government institutions. The research design used is a survey research. The theoretical model is empirically tested with data collected from 130 work units involving 185 respondents from across the local government institutions in Central Java, Indonesia. Structural equation modeling was used to analyze the data. The results show the influence of social values on the adoption of e-Procurement in government institutions. The study results sugest that volunteering based solidarity affects on usage behavior of e-Procurement. This attitude is influenced by the social expectations of the individual against the social benefits of e-Procurement. Other findings, individuals who have a moderate attitude (compromise and permissive) are likely to have a low intention of the e-Procurement. This paper offers a model of development for the government adoption of e-Procurement in government institutions through a participatory approach. Implementation of e-Procurement requires the solidarity movement of individuals who voluntarily diffusing technology. This paper is a study on the adoption of e-Procurement in the public sector that involves social factors as the main determinants of technology in performing of adoption behavior. The study's findings provide insight into the importance of the social benefits and social risk in influencing the adoption of e-Procurement.
\end{abstract}

Keywords: E-Procurement; Volunteering; Solidarity; Social Risk; Social Expectancy.

\section{INTRODUCTION}

Procurement of goods and services electronically (e-Procurement) is one of the mechanisms to realize the values of good governance. E-Procurement is one of the major topics in the area of e-Government. This technology is considered necessary to be implemented in the public

a Corresponding author: Hery Suliantoro, Department of Industrial Engineering, Faculty of Engineering, Diponegoro University, Jl. Prof. H. Soedarto, SH, Semarang, Indonesia. Phone: +62 0815662 4573, E-mail: suliantoro_hery@yahoo.com 
sector in order to realize the values of good governance, such as transparency, accountability, and integrity in the procurement of goods and services (Vaidya et al, 2006). Since 1999, e-Procurement has a more important role than the auction catalog online and digital versions (Ageshin, 2001). Popularity of internet use has significantly affected the institution intention to apply e-Procurement (Vaidya et al, 2006).

According to Matthews (2005), vulnerability discovered from the previous system has led to the development of e-Procurement in the government. The issue about public accountability of conventional procurement process also becomes an ethical issue. Whereas the procurement of goods and services is the most significant activity of the government, not only in terms of the amount of activity, but also the funds allocated (Moon, 2005).

At first, the implementation of e-Procurement in the public sector is expected to increase the efficiency of public organizations such as the business sector. E-Procurement in turn also expected to establish a national internet-based market (Oliveira and Amorim, 2001). In addition to efficiency, the application of e-Procurement in the government also intended to increase the effectiveness, transparency and fairness (equity) between citizens in the provision of goods and services (Dooley and Purchase, 2006; Majdalawieh and Bateman, 2008).

Several studies have been conducted to determine the critical success factors of e-Procurement adoption process. However, these studies still produce different conclusions. MacManus (2002) suggests that the factor inhibiting the implementation of e-Procurement in the public sector especially is a problem employee skill in running an e-Procurement. Reddick (2004) more to see that performance management will determine the success of the development of e-Procurement. Regarding the size of the organization and the role of organizational culture, Moon (2005) concluded that the greater the size of the organization and the innovative culture of the organization will be more active in the government to adopt a wide range of e-Procurement. Further, Dooley and Purchase (2006) expressed the strong positive effect of participation and attention provider of goods/services to the implementation of e-Procurement. Factor "human" by Vaidya et.al (2006) assessed as the most prominent factors in successful implementation of e-Procurement. Other different conclusions stated by Walker and Harland (2008) that the type of organization, organizational readiness to initiate e-Procurement, the procurement strategy, procurement documentation and information technology influence the adoption of e-Procurement.

In response to the conclusions of the different studies, Straub (2009) found that technology adoption is a complex process, socially embedded, depending on the uniqueness of the individual's perception and involves cognitive, emotional and contextual. To answer these differences, this study proposed a social value perspective as one of the main factors that determine the adoption of e-Procurement in government institutions.

\section{LITERATURE REVIEW}

The literature has provided a number of studies to examine the main determinants of technology adoption. Hall (1979) in the Concerns-Based Adoption Model (CBAM) stated that the integration of innovation is influenced by how much individual attention to innovation. One 
of the assumptions of this model that is the innovation is a process that requires growth and development (Hord, Rutherford, Huling-Austin, \& Hall, 1987). The basic components of this model are the individual characteristics and the characteristics of the innovation. Furthermore, Roger in innovation diffusion theory (IDT) said that innovation is an idea, practice or object perceived as a new by an individual or other unit of adoption (Rogers, 1995). There are four basic components that affect the diffusion of technologi: innovation, communication channels, time and social system.

Furthermore, several models were developed using the technology adoption behavior of individual approach that is the Theory of Reasoned Action (TRA) proposed by Fishbein and Ajzen (1975). According to this theory, individual behavior is driven by the intention of the individual to such behavior. Intention is determined by individual attitudes toward the behavior and by subjective norms from the outside in the form of social pressure. This theory was later developed into the theory of planned behavior (TPB) by Ajzen $(1985,1991)$ by adding the construct of perceived behavioral control to eliminate the limitations of the TRA in dealing with behavior in which a person can not fully able to control their desires.

Based on the TRA, Davis (1989) proposed Technology Acceptance Model (TAM). In this model, Davis stated that the use of technology is influenced by the individual's intentions toward technology. This intention is determined by how the individuals attitude (positive or negative feelings) for these technologies. This attitude is dependent on the individual's perception of ease (perceived ease of uses) and usability (perceived usefulness). Other studies that use the TRA / TPB included using the software Lotus 123 at the University (Mathieson, 1991); word processing software business graphics program (Davis et al, 1992), the use of technology in the University Computer Center (Taylor and Todd, 1995); interactive online help desk system (Venkatesh, 2000), the world wide web and the internet (Moon and Kim, 2001); touch screen ordering system (Dabholkar \& Bagozzi, 2002). Furthermore, Venkatesh et al (2003) proposed United Theory of Acceptance and Use Technology (UTAUT) to include constructs from theory and previous models such as social cognitive theory, the theory of reasoned action (TRA), the theory of behavior action (TBA) and innovation diffusion theory (IDT). This theory was put forward four main determinants of performance expectancy, effort expectancy, social influence and facilitating conditions and moderator variables of gender, age, experience and voluntariness of uses.

Referring to the CBAM, IDT, TAM and UTAUT about technology adoption, Straub (2009) draw the general conclusion that the adoption of technology is a complex process, socially embedded, influenced by the perception of the uniqueness of the individual and involves the cognitive, emotional and contextual. Some research on the adoption of e-Procurement is still partially involves several aspects that influence technology adoption. For example, aspects of technology in the form of technology competence (Aguiar and Reis, 2008) and innovation attribute (Zolait, Mattila and Sulaiman, 2009), support systems such as IT capacity (Reddick, 2004), integration with supplier's electronic system (Dooley \& Purchase, 2006), policy and strategic factors (Walker \& Harland, 2008). Personal perception such as attitude toward use (Zolait, Mattila and Sulaiman 2009), organizational factors such as perception about e-procurement companies success of their competitors (Aguiar and Reis, 2008) and 
top management support (Reddick, 2004). Social or contextual factors such as the culture of innovation within a state (Moon, 2005) and supplier adoption (Vaidya et al, 2006).

In the context of government organizations, Alshehri and Drew (2010) identifies some of the challenges of implementing e-government, including poor ICT infrastructure, security and privacy issues, resistance to change to e-systems and culture differences. Ndou (2004) stated that usually moving from paper based to e-service, or any change in society is usually met by some form of resistance. Culture plays a major role in this resistance. Overcoming cultural inertia is one of the main challenges to e-government implementation in developing countries (Ndou, 2004).

In the case of developing countries, e-government initiatives far more difficult because of corruption and rents become a norm. The realignment of information flows and the underlying power structure are heavily resisted by actors with vested interests (Peterson, 1998). If this forms of resistence are not managed using change management or similar initiatives, the gap between the technology and social context in which it operates can not be bridged, (Ndou, 2004).

In Botswana, the adoption rate of e-government services are way below expectation because of lack of citizen awareness and participation (Nkwe, 2012). In Bangladesh, the success factors of e-Government implementation are the strong of change management which includes but not limited to leadership with a project champion, use of incentives to create commitment and ownership of e-government project, and stakeholder involvement to build support and minimize resistance (Hossan, Habib and Kushchu, 2009).

Government procurement is regarded as a measure to limit corruption and encourage efficient administrative operations (ADB Report, 2003). The manual tender system was suffering from the following deficiencies, including cartel formation to suppress competition, physical threats to bidders, human interface at every stage and lack of transparency (Bikshapathi, Rama Raju and Subhash, 2006).

Based on these theories, models and research about technology adoption and e-Procurement, the focus of this study is to prove that in the government institutions, the social aspect has a strong influence on individual decision to adopt e-Procurement.

\section{RESEARCH MODEL}

\subsection{Intention towards e-Procurement}

Fishbein \& Ajzen (1975), states that the intention is a closest cognitive antesenden to the actual behavior. Several studies have shown the relationship between intention and behavior is highly correlated (Armitage \& Conner, 2001; Notani, 1998; Sheppard, Hartwick \& Warshaw, 1988). Research conducted by Davis et al., (1989), Taylor and Todd (1995); Venkatesh and Davis (2000) also showed that this intention is a good predictor of the use of technology. Several other studies also use the intention in predicting the behavior of the use of technologies such as intention to use (Mathieson, 1991), behavioral intention (Taylor and Todd, 1995) and behavioral intention to use (Zolait, Mattila and Sulaiman, 2009). Thus the following hypothesis: 
H1: Intention towards e-Procurement has a positive effect on the usage behavior of e-Procurement

\subsection{Volunteering Based Solidarity (VBS)}

Volunteering is a social action performed by individuals for help other without coercion (Van Til, 1988) and exceeded responsibility (Ellis and Noyes, 1990). The lower voluntarily behavior of individuals it will also lower a person's attitude in the use of technology (Moore, 1989). Solidarity describes integrative bonding within individuals, between individuals and social units in which they are located (Baker et al., 2004). It's characteristics are the identity, substitution, complementarity, exchange, kinship and recovery (Waterman et al., 2001).

Previous studies mentioned subjective norm is an important factor for consideration an individual to adopt technology when the use of technology was not done voluntarily (Hartwick and Barki, 1994). Voluntariness is a moderator variable relationship between social norms and intention (Venkatesh et al, 2003). Volunteerism plays a mediating role in influencing attitudes toward technology (Noyes and Garland, 2003).

Nkwe (2012) stated the lack of citizen awareness and participation cause the adoption rate of e-government services are way below expectation. The use of incentives to create commitment and ownership of e-government project, and stakeholder involvement to build support and minimize resistance are the success factors of e-Government implementation (Hossan, Habib and Kushchu, 2009).

This study proposed volunteering based solidarity as a development the concept of volunterism in the perspective of social benefits. Volunteering based solidarity (VBS) is a construct of attitude towards technology which is demonstrated through individual active response related with voluntarily based on group solidarity. This attitude will potentially increase the adoption of e-Procurement. This discussion leads to the following hypotheses:

H2: Volunteering based solidarity has a positive effect on intention toward e-Procurement

H3: Volunteering based solidarity has a positive effect on the usage behavior of e-Procurement

\subsection{Social Expectancy (SE)}

The concept of social expectation explained that social norms undergo internalization into groups that provide value to the group as to what should be done to society at large (Hasegawa et al, 2007). Some research about technology adoption proved the role of expectations to influence the use of new technologies. Compeau and Higgins (1995) proposed two constructs influence the acceptance of the technology that are outcome expectation and outcome expectation of personal performance. Venkatesh et al (2003) in the theory of United Theory of Acceptance and Use Technology (UTAUT) proposed the performance expectancy and effort expectancy as determinants of intention to technology. Social expectations will drive a social activity (Bellah et al., 1991). These expectations also motivate voluntary-based activities (Pekkanen, 2003). The voluntary-based activities will contribute to the introduction of new technology to the 
public, creating a protection for the development and learning of new technologies (Hoogma, 2000). The next hypothesis as follows:

H4: Social expectancy has a positive effect on intention toward e-Procurement

H5: Social expectancy has a positive effect on volunteering based solidarity

\subsection{Social Risk Balancing (SRB)}

Previous studies involved normative pressure as different attitudes of the individual to be accepted as a truth (Scott, 2001). In the context of technology adoption, normative pressure would lead someone who did not adopt the new technology will feel awkward and uncomfortable (DiMaggio and Powell, 1983), was a 'foreign' as the center of attention due to adopting new technologies (Kotler and Armstrong, 1996). Adoption of the technology could also lead to the emergence of the risk of compatibility (Roger, 1983), search costs, trial costs and the risks of being a pioneer in the use (Teo, Wei and Benbasat, 2003), level of incongruity of new technologies (Ozanne et al., 1992), unfamiliar to certain technologies (Sujan, 1985), the technology performance data unavailability (Kotler and Armstrong, 1996) and the risk of unpreparedness supporting infrastructure (Venkatesh et al, 2003).

Individual behavior is a reaction to the people or the environment. Individuals may have a different attitude and if this attitude continues to be maintained will cause discomfort (Heider, 1946, 1958). Someone in exchange relationships with other people will expect remuneration comparable to the sacrifices that have been issued (Homans, 1974) and tend to avoid mistakes than to maximize the benefits when faced with risky decisions (Campbell and Goodstein, 2001).

Peterson (1998) stated that corruption and conflict of interest becomes an obstacle to the implementation of e-government. In procurement, the manual tender system was suffering cartel formation to suppress competition, physical threats to bidders, human interface at every stage and lack of transparency (Bikshapathi, RamaRaju and Subhash, 2006). If these forms of resistence are not managed properly it will lead to the emergence of the gap between technology and social issues (Ndou, 2004).

In the context of government procurement in some developing countries, corruption is still common in the procurement. Majdalawieh and Bateman (2008) stated that the application of e-Procurement in the government is able to increase the transparency and fairness (equity). Typically, the corrupt behavior committed by certain parties who have a conflict of interest and access to power. This behavior is carried out by certain parties who have an access to power. Members of government organization stand to resist the implementation of e-procurement because the technology will reduce corrupt behavior, which is carried out by the authorities. Therefore, individual's decision to use the e-Procurement will create an antagonistic relationship or conflict between superiors and subordinates and have a risk of social consequences. 
This study proposed social risk balancing as a technological risk in perspective of social risk. Social Risk Balancing (SRB) is a construct of attitude towards technology which is demonstrated through individual passive response in the form of permissiveness and compromise to face differences social attitudes about technology. This attitude will potentially lower the adoption of e-Procurement. Therefore, the hypothesis is as follows:

H6: Social risk balancing has a negative effect on intention toward e-Procurement

H7: Social risk balancing has a negative effect on the usage behavior of e-Procurement

Figure 1: Research Model

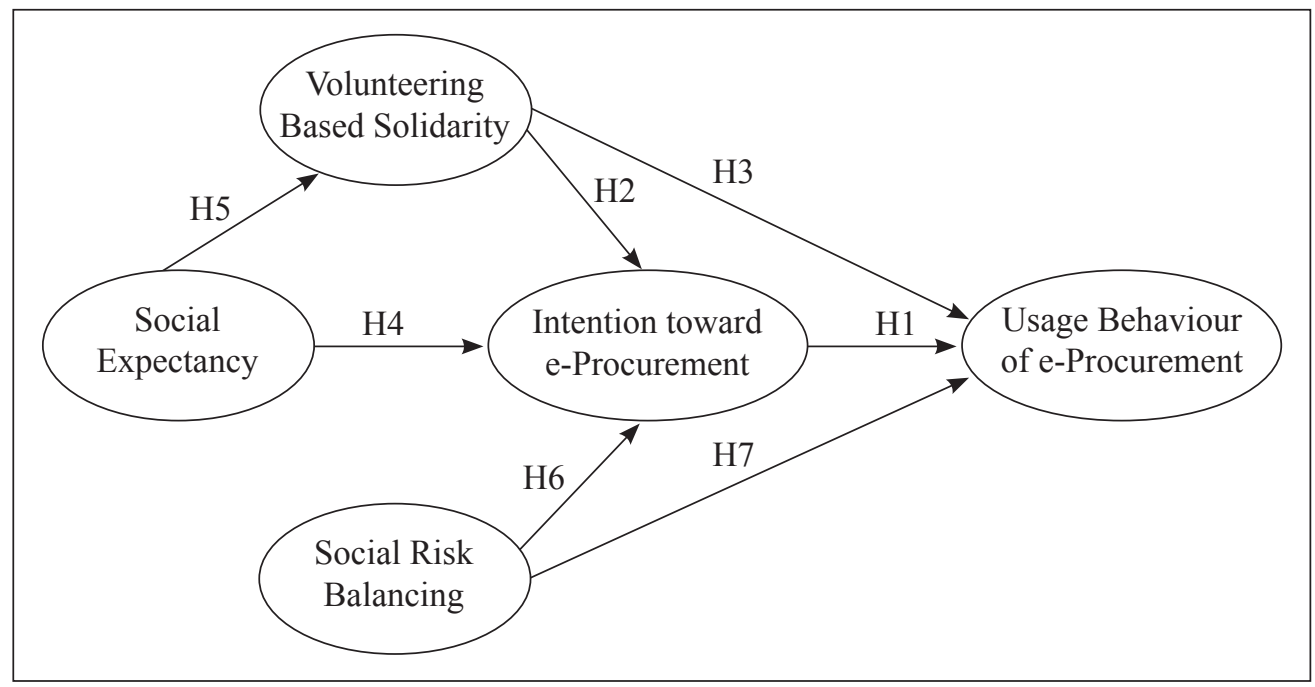

\section{RESEARCH METHOD}

The research survey is used to test the research model. Unit of analysis is the work unit on the Provincial Government agencies and State University who has been using the e-Procurement system. The population of users of the system as many as 359 units and as many as 130 the number of sample units and the number of respondents as many as 185 personnel. Respondents in this study were government employees who have been using the e-Procurement.

Data analysis was performed using analysis of evaluation measurement (outer model) and an analysis of the structural model (inner model). Structural model was tested using Structural Equation Modelling-Smart PLS. Descriptive analysis of the open-ended questions was also performed to explore qualitatively and complement the research findings. 
Table 1: Measurement

\begin{tabular}{|c|c|c|}
\hline Construct & Measurement & References \\
\hline \multicolumn{3}{|c|}{ Usage behavior of e-Procurement (USE) } \\
\hline USE1 & Full utilization & Fishbein and Ajzen (1975), Igbaria et al. \\
\hline USE2 & Frequency of use & (1995), Davis et al (1989) \\
\hline USE3 & Time duration of use & \\
\hline USE4 & Value of procurement (Rp) & \\
\hline USE5 & Size of procurement & \\
\hline \multicolumn{3}{|c|}{ Intention toward e-Procurement (INT) } \\
\hline INT1 & Tendency to use & Fishbein and Ajzen (1975), Venkatesh \\
\hline INT2 & Possibility to use & and Davis (2000), Lada et al. (2008) \\
\hline INT3 & Plan to use & \\
\hline INT4 & Decision to use & \\
\hline \multicolumn{3}{|c|}{ Volunteering Based Solidarity (VBS) } \\
\hline VBS1 & Pioneers, initiator of group & Durkheim (1988), Mead (1934), \\
\hline VBS2 & Ties and commitment to the group & Baker et al. (2004), (1980), \\
\hline VBS3 & Identity and pride of group & Straub (2009) \\
\hline VBS4 & Integration of group's resources & \\
\hline VBS5 & The purpose of group & \\
\hline \multicolumn{3}{|c|}{ Social Expectancy (SE) } \\
\hline SE1 & $\begin{array}{l}\text { Performance expectations of } \\
\text { public services }\end{array}$ & $\begin{array}{l}\text { Hall (1979), Hord, Rutherford, } \\
\text { Huling-Austin, \& Hall (1987) }\end{array}$ \\
\hline SE2 & Expectations of public interest & \\
\hline SE3 & Expectations of social welfare & \\
\hline \multicolumn{3}{|c|}{ Social Risk Balancing (SRB) } \\
\hline SRB1 & Perform improper behavior & Heider $(1946,1958)$, Bauer (1960), \\
\hline SRB2 & Conscience avoid disputes & Fraedrich and Ferrell (1992), \\
\hline SRB3 & Acted outside the procedure & Havlena dan DeSarbo (1991) \\
\hline
\end{tabular}

\section{RESULTS}

Data analysis was performed in 2 (two) stages of evaluation measurement (outer model) and tested the structural model (inner model). First, the evaluation of measurement (outer model) of empirical models; obtained convergent validity values $(>0.7)$, average variance extrated $(>0.5)$, composite reliability $(>0.7)$, cronbachs alpha $(>0.7)$ and discriminant validity are eligible. Second, the test result of the structural model (inner model); the model shows the value of goodness-fit models are moderate with a value from 0.234 to 0.265 . Table 2 illustrates the output of SmartPLS. 
Table 2: Evaluation Measurement (Outer Model): AVE, CR, CA, T-Values

\begin{tabular}{|c|c|c|c|c|c|}
\hline & Outer Loading & $\sqrt{ } \mathbf{A V E}$ & $\begin{array}{l}\text { Composite } \\
\text { Reliability }\end{array}$ & $\begin{array}{c}\text { Cronbachs } \\
\text { Alpha }\end{array}$ & T Statistics \\
\hline \multicolumn{2}{|c|}{ Behavioral use of e-Procurement } & 0,818 & 0,909 & 0,872 & \\
\hline USE1 & 0,752027 & & & & 15,689 \\
\hline USE2 & 0,676167 & & & & 10,711 \\
\hline USE3 & 0,848729 & & & & 27,909 \\
\hline USE4 & 0,900981 & & & & 37,819 \\
\hline USE5 & 0,888336 & & & & 34,492 \\
\hline \multicolumn{2}{|c|}{ Intention toward e-Procurement } & 0,900 & 0,945 & 0,921 & \\
\hline INT1 & 0,917751 & & & & 33,786 \\
\hline INT2 & 0,797779 & & & & 9,597 \\
\hline INT3 & 0,940743 & & & & 72,534 \\
\hline INT4 & 0,937533 & & & & 72,023 \\
\hline Social Expectancy & 0,819 & 0,859 & 0,754 & & \\
\hline SE1 & 0,821315 & & & & 19,826 \\
\hline SE2 & 0,891043 & & & & 60,517 \\
\hline SE3 & 0,738088 & & & & 15,736 \\
\hline \multicolumn{2}{|c|}{ Social Risk Balancing } & 0,698 & 0,723 & 0,528 & \\
\hline SRB1 & 0,638816 & & & & 1,545 \\
\hline SRB2 & 0,381202 & & & & 1,486 \\
\hline SRB3 & 0,861229 & & & & 1,704 \\
\hline \multicolumn{2}{|c|}{ Volunteering Based Solidarity } & 0,715 & 0,831 & 0,755 & \\
\hline VBS1 & 0,650429 & & & & 9,294 \\
\hline VBS2 & 0,817556 & & & & 22,147 \\
\hline VBS3 & 0,357808 & & & & 3,056 \\
\hline VBS4 & 0,805227 & & & & 13,419 \\
\hline VBS5 & 0,830889 & & & & 23,556 \\
\hline
\end{tabular}

Latent variable correlations Table 3 below shows that the roots of AVE (diagonal elements) have a higher value than the value of the correlation between the other constructs. This proves that all the constructs USE, INT, SE, SRB and VBS has good discriminant validity.

Table 2: Latent variable correlations

\begin{tabular}{lccccc}
\hline & USE & INT & SE & SRB & VBS \\
\hline Behavioral use e-Procurement (USE) & $\mathbf{0 , 8 1 8}$ & & & & \\
Intention toward e-Procurement (INT) & 0,350 & $\mathbf{0 , 9 0 0}$ & & & \\
Social Expectancy (SE) & 0,263 & 0,429 & $\mathbf{0 , 8 1 9}$ & & \\
Social Risk Balancing (SRB) & $-0,143$ & $-0,219$ & $-0,191$ & $\mathbf{0 , 6 9 8}$ & \\
Volunteering Based Solidarity (VBS) & 0,446 & 0,404 & 0,514 & $-0,202$ & $\mathbf{0 , 7 1 5}$ \\
\hline
\end{tabular}

Notes: Bold numbers on the diagonal are the square root of the variance shared between the constructs (average variance extracted) and their measures. Off-diagonal elements are correlations among constructs. For discriminant validity, diagonal elements should be larger than off-diagonal elements. 
Test of the inner model was performed to see of the relationship between constructs, as well as the value of significance and R-square. Test of goodness-fit model of the structural model (inner model) was performed by looking at the value of R-square. R-square value of $0.19,0.33$ and 0.67 for the endogenous latent variables in the structural model indicates that the model is weak, moderate and good. The following table provides estimates of the output. Table 3 below provides the output estimate.

Table 4: Testing a structural model (inner model): R-Square

\begin{tabular}{cc}
\hline & R Square \\
\hline USE & 0,234352 \\
INT & 0,243169 \\
SE & \\
SRB & \\
VBS & 0,264749 \\
\hline
\end{tabular}

Table 4 above shows that the model is quite good to describe the effect of the latent constructs are independent to the latent constructs.

The test results of the structural model (inner models) shown in Figure 2 below. Intention towards e-Procurement (INT) has a positive effect on usage behavior of e-Procurement (USE) $(\beta=0.198, \mathrm{p}<0.05)$. Volunteering based solidarity (VBS) has a positive effect on INT $(\beta=0.233$, $\mathrm{p}<0.05)$ and positive effect on usage behavior of e-Procurement (USE) $(\beta=0.361, p<0.001)$. Social expectancy (SE) has a positive effect on VBS $(\beta=0.515, \mathrm{p}<0.001)$ and positive effect on the INT $(\beta=0.287, \mathrm{p}<0.001)$. Next, balancing social risk (SRB) has a negative effect on INT $(\beta=-0.118, p<0.1)$. Nevertheless SRB has no effect on the usage behavior of e-Procurement (USE).

Figure 2: Results



Notes : significance $* * * \mathrm{p}<0,01 * * \mathrm{p}<0,05 * \mathrm{p}<0,10$. 
Figure 2 above shows that $26.5 \%$ of the VBS variability explained by SE $\left(\mathrm{R}^{2}=0.265\right)$. VBS, SE and SRB overall explain $24.3 \%$ variability of INT $\left(\mathrm{R}^{2}=0.243\right)$. Furthermore $23.4 \%$ variability of USE can be explained by VBS and INT $\left(\mathrm{R}^{2}=0.234\right)$.

\section{DISCUSSION}

First, the analysis shows that the intentions of the individual toward e-Procurement has a positive effect on usage behavior of technology is shown by the value of coefficient $=0.198$ (95\% confidence level). These findings support the view of Ajzen $(1985,1991)$ who stated that intention is the closest cognitive antesenden of actual behavior. Someone will do a behavior if he has a desire or intention (behavioral intention) to do so. In connection with the adoption of information technology, these findings also reinforce support for technology acceptance model proposed by Davis (1986) and Venkatesh et al (2003).

Second, the analysis found that volunteering based solidarity has a positive effect on the intention toward e-Procurement. It is indicated by the value of coefficient $=0.233(95 \%$ confidence level). Volunteering based solidarity also showed has a strong positive effect on usage behavior of e-Procurement with a coefficient $=0.361$ (99\% confidence level). The results of the statistical analysis also showed that the direct effect of volunteering based solidarity to use of e-Procurement is stronger than its influence indirectly through intentions. This study confirms what Katz \&Stotland (1959), Kothandapani (1971) and Triandis (1964) which states that behavior can be predicted by his attitude when attitudes are measured not only involves the affective component alone, but rather on behavioral components (conative). Volunteering based solidarity is an attitude that measure aspects of behavioral (conative), which describes the tendency of individuals to perform communal social activities voluntarily and unconditionally (free will) to use and diffuse e-Procurement.

Third, the analysis found that the social expectancy has a positive influence on the intention toward e-Procurement with a coefficient of 0.287 (99\% confidence level). Social expectancy also showed a positive and significant impact on volunteering based solidarity with the positive effect $=0.514(99 \%$ confidence level $)$. Thus social expectancy is an antesenden factor of volunteering based solidarity and intention towards e-Procurement. This study supports the idea that social expectations will drive a social activity (Bellah et al., 1991) and motivate activities based on voluntary (Pekkanen, 2003). Social expectancy shows individual social expectation that e-Procurement would benefit the interests of the various parties or the public.

Fourth, the analysis found that social risk balancing has a negative effect on intention toward e-Procurement indicated by the value of coefficient $=-0.117$ ( $90 \%$ confidence level). However, social risk balancing showed no significant negative effect on usage behavior of e-Procurement with coefficient of $-0.026(90 \%$ confidence level). This result proves that the social risk balancing is antesenden of intentions but not antesenden of usage behavior of e-Procurement.

\section{CONCLUSION AND RECOMMENDATION}

Through the social values perspective, this study shown that the usage behavior of e-Procurement in government institution is determined by how high the group solidarity 
which is based on voluntariness to use these technologies (volunteering based solidarity). This attitude can be built through social expectations of individuals about the benefits of this technology to the public (social expectancy). The next aspects of social values is align risk attitudes (social risk balancing). This attitude negatively effects on intention toward e-Procurement. It means that if an individual has a high align social risk attitude then the intention toward e-Procurement will be lower and in turn will lower the usage behavior of this technology.

The most important theoretical implication of the findings of this research is to improve the original concept of the adoption of technology as follows. First, this study rejected the view that intention is a closest cognitive antesenden to the actual behavior. Volunteering based solidarity proposed in this study as aconstructs of attitude shows that the higher group solidarity that is based on voluntariness towards the use of e-Procurement; directly influence intentions and increase usage behavior of this technology. This study provides support for the importance of using the construct of attitude involving aspects of behavioral (conative) in order that attitudes can better predict intentions and behavior. Second, the results showed that the social expectancy is antesenden of volunteering based solidarity. Social expectancy is a construct that indicates the individual expectation that the technology will provide beneficial effects for many parties. Awareness of the social benefits of e-Procurement encourages voluntarily attitudes of group, in turn will increase significantly the use of e-Procurement. Third, another important contribution of this study is put forward the construct social risk balancing that show a negative effect on intention toward e-Procurement. This construct describes the individual's responses to the attitude of the organization related to the presence of e-Procurement; in the form of negative responses tend to avoid risk and social conflict. The higher this attitude of the individual, the lower their intention to use the e-Procurement.

Several important implications for policy makers of the findings of this study is the adoption of e-Procurement in government institution as a socially embedded process that requires a social movement in the diffusion process so as to transform this technology into social needs, rather than the needs of the individual and organizational nature.

The important implications for the government is as a socially embedded process, the adoption of e-Procurement requires a social movement in the process of diffusion. Social participation was started by a group of individuals in government institutions understand the broad social benefits of e-Procurement. Group of individuals is also conducting group solidarity based on voluntary activities to diffuse this technology in the agency. Therefore, the Government needs to encourage the emergence of e-Procurement user initiator at governmental institutions through capacity building access and support resources.

The main limitations of this research model lies in the relatively small number of R-square for variables endogenos intentions towards e-Procurement and e-Procurement usage behavior that is the subject of the research issue. This figure shows that there are other variables as well as antesenden of intention and usage behavior of e-Procurement so we need a more in-depth exploration for other variables. 


\section{ACKNOWLEDGEMENTS}

The authors thank Lembaga Kebijakan Pengadaan Barang/Jasa Pemerintah (LKPP) Indonesia for funds the research, Bambang Purwanggono, and Ikak G. Patriastomo for comments on earlier draft of this manuscript.

\section{REFERENCES}

Ageshin, E. A. (2001). E-Procurement at work: A case study. Production and Inventory Management Journal, First Quarter, 4248.

Aguiar, A., \& Reis, A. (2008). Why do firms adopt e-procurement systems? Using logistic regression to empirically test a conceptual model. IEEE Transactions on Engineering Management, 55(1), 120-133.

Ajzen, I. (1985). From Intentions to Action: A Theory of Planned Behaviour. In J. Kuhl \& J. Beckman (Eds.), Action control: From cognitions to behaviors. New York: SpringerVerlag.

Ajzen, I. (1991). The theory of planned behavior. Organizational Behavior and Human Decision Processes, 50(2), 179 - 211.

Alshehri, M., \& Drew, S. (2010). Challengesof e-Government Services Adoption in Saudi Arabia from an e-Ready Citizen Perspective. World Academy of Science, Engineering and Technology, 42, 1039-1045.

Armitage, C. J., \& Conner, M. (2011). Efficacy of the Theory of Planned Behaviour: A metaanalytic review. British Journal of Social Psychology, 40, 471-499.

Asian Development Bank (ADB). (2003). Peoples Republic of China Readiness for Electronic Government Procurement Survey. Asian Development Bank.

Baker, R . S., Corbett, A.T., Koedinger, K.R., \& Wagner, A.Z. (2004). Off-Task Behavior in the Cognitive Tutor Classroom: When Students "Game the System". Proceedings of ACM CHI: Computer-Human Interaction. Vienna, Austria.

Bauer, R. A. (1960). Consumer Behavior as Risk Taking. In R. S. Hancock (Eds.), Dynamic Marketing for a Changing World. Proceedings of the 43rd National Conference of the American Marketing Association.

Bellah, R., Madsen, R., Sullivan W. M., Swidler, A. \& Tipton S. M. (1991). The Good Society. New York: Alfred A. Knopf.

Bikshapathi, K., RamaRaju, P., Bhatnagar, S \& Ahmedabad, I. (2006). E- Procurement in Government of Andhra Pradesh, India. Retrieved April, 10, 2010, from http://web. worldbank.org/. 
Campbell, M. C., \& Goodstein R. C. (2001). The moderating effect of perceived risk on consumers' evaluations of product incongruity: Preference for the norm. Journal of Consumer Research, 28(3), 439-449.

Compeau, D. R., \& Higgins, C. A. (1995). Computer Self-Efficacy: Development of a Measure and Initial Test. MIS Quarterly, 19(2), 189-211.

Dabholkar, P. A., \& Bagozzi, R. P. (2002). An attitudinal model of technology-based selfservice: moderating effects of consumer traits and situational factors. Journal of the Academy of Marketing Science, 30(3), 184-201.

Davis, F. D. (1986). A technology acceptance model empirical testing new end-user information systems: theory and results. Doctoral dissertation, Sloan School of Management, Massachusetts Institute of Technology, Cambridge, M.A.

Davis, F. D. (1989). Perceived usefulness, perceived ease of use, and user acceptance of information technology. MIS Quarterly, 13(3), 319 -339.

Davis, F. D., Bagozzi, R.P., \& Warshawa, P.R. (1989). User acceptance of computer technology: a comparison of two theoretical models. Management Science, 35(8), 982-1003.

Davis, F. D., Bagozzi, R.P., \& Warshawa, P. R. (1992). Extrinsic and Intrinsic Motivation to Use Computer in the Workplace. Journal of Applied Social Psychology, 22(14), 11111132.

DiMaggio, P. J., \& Powell, W. W. (1983). The iron cage revisited: Institutional isomorphism and collective rationality in organizational fields. American Sociological Review, 48(2), $147-160$.

Dooley, K., \& Purchase, S. L. (2006). Factors Influencing EProcurement Usage. Journal of Public Procurement, 6(1/2), 28-45.

Durkheim, E. (1988). Les Re'gles de la Me'thode Sociologique. Paris: Flammarion.

Ellis, S. J., \& Noyes, K. H. (1990). By the People: A History of Americans asVolunteers. (rev. ed.) San Francisco: Jossey-Bass.

Fishbein, M., \& Ajzen, I. (1975). Belief, Attitude, Intention, and Behavior: An Introduction to Theory and Research. Reading, MA: Addison-Wesley.

Fraedrich, J., \& O. C. Ferrell. (1992). The Impact of Perceived Risk and Moral Philosophy Type on Ethical Decision Making in Business Organizations. Journal of Business Research, 24(4), 283-295.

Hall, G.E. (1979). The concerns-based approach to facilitating change. Educational Horizons, 57, 202-208. 
Hartwick, J., \& Barki, H. (1994). Explaining the Role of User Participation in Information System Use. Management Science, 40(4), 440-465.

Hasegawa, K., Shinohara, C., \& Broadbent, J. P. (2007). The Effects of 'Social Expectation' on the Development of Civil Society in Japan. Journal of Civil Society, 3(2), 179-203.

Havlena, W. J., \& DeSarbo, W. S. (1991). On the Measurement of Perceived Consumer Risk. Decision Sciences, 22, 927 - 939.

Heider, F. (1946). Attitudes and cognitive organization. Journal of Psychology, 21, 107-112.

Heider, F. (1958). The psychology of interpersonal relations. New York: Wiley.

Homans, G. C. (1974). Social behavior and its elementary forms. New York: Harcourt, Brace and World.

Hoogma, R. (2000). Exploiting Technological Niches. Enschede: Twente University Press.

Hord, S. M., Rutherford, W.L., Huling-Austin, L., \& Hall, G.E. (1987). Taking charge of change. Alexandria, VA: Association for Supervision and Curriculum Development.

Hossan, C. G., Habib, M. W., \& Kushchu, I. (2009). Success and Failure Factors for e-Government projects implementation in developing countries: A study on the perception of government officials of Bangladesh. In G. Usha (Eds.), E-Governance: Policy and Perspectives (pp.136-151). Hyderabad: ICFAI University Press.

Igbaria, M., \& Iivari, J. (1995). The Effects of Self-Efficacy on Computer Usage. Omega, 23(6), 587-605.

Katz, D., \& Stotland, E. (1959). A preliminary statement to a theory of attitude structure and change. In S. Koch (Eds.), Psychology: A study of a science (pp. 423-475). New York: McGraw-Hill.

Kothandapani, V. (1971). Validation of feeling, belief, and intention to act as three components of attitude and their contribution to prediction of contraceptive behavior. Journal of Personality and Social Psychology, 19(3), 321-333.

Kotler, P., \& Armstrong, G. (1996). Principles of Marketing, $7^{\text {th }}$ ed. Englewood Cliffs, NJ: Prentice-Hall

Lada, S., Tanakinjal, G. H., \& Amin, H. (2008). Predicting intention to choose halal products using theory of reasoned action. International Journal of Islamic and Middle Eastern Finance and Management, 2(1), 66-76. 
MacManus, S, A. (2002). Understanding The Incremental Nature of E-Procurement Implementation at the State and Local Level. Journal of Public Procurement, 2(1), 5-28.

Majdalawieh, M., \& Bateman, R. (2008). Tejari And E-Procurement: Moving To Paperless Business Processes. Journal of Information Technology Case and Application Research, 10(1) 52-69.

Mathieson, K. (1991). Predicting user intention: comparing the technology acceptance model with the theory of planned behavior. Information Systems Research, 2(3), 173-191.

Matthews, D. (2005). Strategic Procurement In The Public Sector: A Mask For Financial And Administrative Policy. Journal of Public Procurement, 5(3), 388-399.

Mead. (1934). Mind Self and Society. Chicago, IL: University of Chicago Press.

Moon, J-W., \& Kim, Y-G. (2001). Extending the technology acceptance model for the worldwide- web context: Playfulness as a sailent belief. Information \& Management, 38, 217 230 .

Moon, M. J. (2005). E-Procurement Management In State Governments: Diffusion Of E-Procurement. Journal of Public Procurement, 5(1), 54-72.

Moore, M. G. (1989). Editorial: Three types of interaction. The American Journal ofDistance Education, 3(2), 1-7.

Ndou, V. (2004). E-government for developing countries: opportunities and challenges. The Electronic Journal on Information Systems in Developing Countries. 18(1), 1-24.

Nkwe, N, (2012). E-Government: Challenges and Opportunities in Botswana. International Journal of Humanities and Social Science, 2(17), 39-48.

Notani, A. S. (1998). Moderators of perceived behavioral control's predictiveness in the theory of planned behavior: A meta-analysis. Journal of Consumer Psychology, 7(3), 247-271.

Noyes, J. M., \& Garland, K. J. (2003). VDT versus paper-based text: Reply to Mayes, Sims and Koonce. International Journal of Industrial Ergonomics, 31(6), 411-423.

Oliveira, L. M. S., \& Amorim, P. P. (2001). Public EProcurement. International Financial Law Review, 20(3), 43-47.

Ozanne, J. L., Brucks, M., \& Grewal, D. (1992). A study of information search behaviour during the categorization of new product. Journal of Consumer Research, 18(March), 452-463. 
Pekkanen, R. (2003). Molding Japanese civil society. In F. J. Schwartz \& S. J. Pharr (Eds.), The State of Civil Society in Japan (pp. 116-134). Cambridge: Cambridge University Press.

Peterson, L. (1998). Saints, Demons, Wizards and Systems: Why Information Tecnology Reforms Fail or Underperform in Public Bureaucracies in Africa. Public Administration and Development, 18(1), 37-60.

Reddick, C. G. (2004). The Growth of E-Procurement in American State Governments: A Model And Empirical Evidence. Journal of Public Procurement, 4(2), 151-172.

Rip, A., \&Velde, R. A. (1997). The dynamics of innovation in bio-engineering catalysis. Cases and analysis. Sevile: Institute for Prospective Technological Studies.

Rogers, E. M. (1983). Diffusion of Innovations (3rd edition). London: The Free Press.

Rogers, E. M. (1995). Diffusion of Innovations. New York: Free Press.

Scott, W. R. (2001). Institutions and Organizations 2nd edn. Thousand Oaks, CA: Sage.

Sheppard, B. H., Hartwick, J., \& Warshaw, P. R. (1988). The theory of reasoned action: Ametaanalysis of past research with recommendations for modifications and future research. Journal of Consumer Research, 15(3), 325-343.

Straub, E. T. (2009). Understanding Technology Adoption: Theory and Future Directions for Informal. Review of Educational Research, 79(2), 625-649.

Sujan, M. (1985). Consumer knowledge: effects on evaluation strategies mediating consumer judgments. Journal of Consumer Research, 12(June), 31-46.

Taylor, S., \& P. A. Todd. (1995). Understanding Information Technology Usage: A Test of Competing Models. Information Systems Research, 6(2), 144-176.

Teo, H. H., Wei, K. K., \& Benbasat, I. (2003). Predicting intention to adopt interorganizational linkages: An institutional perspective. MIS Quarterly, 27(1), 19 -49.

Triandis, H. C. (1964). Exploratory factor analyses of the behavioral component of social attitudes. Journal of Abnormal and Social Psychology, 68(4), 420-430.

Vaidya, K., Sajeev, A. S. M., Callender, G. (2006). Critical Factors That Influence E-Procurement Implementation Success in the Public Sector. Journal of Public Procurement, 6(1\&3), 70-99.

Van Til, J. (1988). Mapping the third sector: Voluntarism in a changing social economy. New York: The Foundation Center. 
Venkatesh, V. (2000). Determinants of perceived ease of use: integrating control, intrinsic motivation, and emotion into the technology acceptance model. Information Systems Research, 11, 342-365.

Venkatesh, V., \& Davis, F.D. (2000). A theoretical expansion of the technology acceptance model: four longitudinal field studies. Management Science, 46(2), 186-204.

Venkatesh, V., Morris, M. G., Davis, G. B., \& Davis, F. D. (2003). User acceptance of information technology: Toward a unified view. MIS Quarterly, 27(3), 425 - 478.

Walker, H., \& Harland, C. (2008). E-procurement in the United Nations: influences, issues and impact. International Journal of Operations \& Production Management, 28(9), 831857.

Waterman, H., Tillen, D., Dickson, R., \& de Konig, K. (2001). Action research: a systematic review and guidance for assessment. Health Technology Assessment, 5(23), iii-157.

Zolait, A. H. S., Mattila, M., \& Sulaiman, A. (2009). The effect of user's informational-based readiness on innovation acceptance. International Journal of Bank Marketing, 27(1), 76-100. 